\title{
FAMILIES OF STREET CHILDREN IN THE TRANSKEI: A DEVELOPMENTAL PERSPECTIVE
}

\section{T Mashologu-Kuse}

\section{INTRODUCTION}

In South Africa, as elsewhere in the world, there is a paucity of literature on families of street children. A recent literature search (on the internet and in other resources) reveals that reasons for this state of affairs are many, some of the main ones being:

- The tendency on the part of researchers to investigate the "obvious", in this case the children roaming the streets, instead of viewing the phenomenon in depth, i.e. taking cognisance of the root causes of the problem. Thus, resources that seek to investigate the phenomenon are likely to be misdirected towards addressing the problem after it has occurred, rather than examining its causes. Also, focusing on the phenomenon of street children negates the fact that a child is part of a family and thus can never be rehabilitated in isolation from his family, hence this study to determine the "character" of families of street children.

- The difficulty researchers have in locating families of these children since the children have de-bonded from their families for a variety of reasons, some of which are: family disorganisation, poverty at home, school-related problems, a breakdown of social networks in the community as well as disillusionment with the existing societal values, hope for an alternative glamorous life-style, to mention just a few (http://web24.epnet.com/citation, 2006; Kuse, 2001). In the Transkei, where this study was conducted, families were "traced" through links with the extended kin who had sheltered the street children after leaving their biological families to fend for themselves.

In the present study, the researcher seeks to determine the characteristics of these families with a view to understanding the environment from which the street children come.

\section{SIGNIFICANCE OF FAMILIES}

In South Africa the family is still regarded as the normal biological and social structure, which should guide the growth and development of a child. "This perception still underpins the political mindset in South Africa and informs social policy, as it does in many parts of the world" (SwartKruger, 1996:233). A study conducted in Johannesburg on inmates of two shelters indicates that half of the sample of the 97 street boys interviewed expressed a genuine desire to return to their families or even find a substitute family (Richter \& Van der Walt, 1996). In another study, also conducted in Johannesburg, nearly half of the sample had frequent contact with their families (Richter \& Van der Walt, 1996:218). This has often been endorsed by researchers world-wide, who believe that many street children are working in the streets and at the end of the day go back to their families (Aptekar, 1996; Richter \& Swart-Kruger, 1996; Swart-Kruger \& Donald, 1994 in Dawes \& Donald, 1994; Black, 1993; Richter, 1989). In South Africa these children are referred to as "children on the streets" (Richter, 1989). They are temporarily on the streets to work, but maintain contact with their families at the end of the day. This clearly indicates the value and the significance of families.

One way of understanding the significance of the family is to look at the functions of the family. The family provides the basic material goods for the survival, growth and development of the child. It nurtures its young, provides affection and as the children grow, it becomes a powerful 
socialising agent, shaping the individual's capacity for personal relationships and preparing him for the complex world. It provides the individual with a continuity of identity, a network of relations, his roots of the past as well as his branches for the future. It promotes the individual's growth and, because of its dynamic quality, its functions change over time in terms of its members' needs and problems (Pandey, 1991).

In addition to the functions that the family executes, the significance of the family can also be noted by looking at the role the family plays in society. Externally, family members relate to other people and institutions. The family has a crucial function which is central to the stability and continuity of human society, that of producing "healthy" citizens. The production of healthy citizens with a potential for sustaining the political, social and economic growth as well as the moral dignity of the country depends on effective family functioning and on how well a family can adapt to changing environmental demands.

"Traditionally", the family is viewed as a social collective unit that provides protection and assists the individual in confronting the sometimes stressful demands of daily life. "Ideally, one's family should always exist as an oasis, a place that is safe and satisfying, where one can seek relief from, and aid in dealing with, the often stressful demands of the outside world" (Pandey, 1991:137). The family should also serve as a sanctuary for the spiritual growth of its besieged members. Unfortunately, this is not the case with families of street children; hence the present study seeks to determine the characteristics of families of street children.

\section{CONCEPTUAL FRAMEWORK}

Past research on the causes of children being on the streets produces contradictory findings, because of lack of agreement amongst researchers on the cause of the problem. For example, Williams (1996) is of the opinion that family violence is the main reason for children leaving home. Pandey (1991) believes that children leave their homes because of lack of support on the part of caregivers in the home environment. Brennan, Huizinga and Elliot (1978) believe that girls run away from home because of a rejecting home environment. Young, Godfrey, Matthews and Adams (1983) believe that high-flown parental expectations are a major pressure leading to children running away from home. Gullotta (1979) is of the opinion that sexual and physical abuse at home are the major causes for children leaving home.

All of these point to family circumstances that impact negatively on the child. These assertions stimulated the inquisitiveness of the researcher to seek to identify the "character" of these families.

In the next few paragraphs the researcher attempts to present different theories or perspectives on the aetiology of the street-child phenomenon as well as consider studies that have been conducted to substantiate some of these theories.

Melson (1991) discerned three major perspectives or causes of the phenomenon of street children, namely, the psychopathological perspective, the normal health perspective and the sociological perspective.

The first model, the psychopathological perspective, was developed from psychiatric literature, case studies and clinical observations made on the kind of youth that were repeat runaways. This model attributes the basic reasons for running away as located within the individual child who is characterized as "...emotionally disturbed, mentally deficient, lacking ego-strength, having poor impulse control and suffering from depression" (Melson, 1991:33). These youths, according to this model, are described as timid, immature, feeling rejected, having few companions and exhibiting inadequate problem-solving abilities (Melson, 1991). 
The second model, the normal-healthy perspective, views the problem of street children as a normal phase of development. Proponents of this theory reject the notion that running away is a manifestation of underlying psychological, personality, family and social problems (Melson, 1991). According to this theory, running away is viewed as a natural step in the normal developmental growing-up process of many youths and should therefore be regarded as a sign of positive psychological growth towards independence and autonomy.

Recent studies indicate a shift from this perception of the phenomenon of street children (McWhirter, McWhirter, McWhirter, \& McWhirter, 1998). They indicate that running away is a coping mechanism, a primary means of coping with danger (Melson, 1991). Here running away can be perceived as a fight response, in which case the youth feels unable to remain in the family and is fighting parental limits (Melson, 1991), once again an indication that the problem may be located within the family.

The third model, the sociological perspective, attributes disturbed family life as a causal factor for youths to run away from their homes (Melson, 1991). The theory postulates that these youths run away from their homes because of their families being dysfunctional as a consequence of economic, marital and communication problems between parents, and between parents and children. The youths are socially and emotionally troubled and have experienced a number of personal problems. They experience strained parent-child relationships and stressful home environments and, because they are victims of dysfunctional families, running away is regarded as fleeing from a stressful environment (Melson, 1991).

A fourth model, the socio-psychological perspective, which is an aspect the above model, focuses the aetiology of children running away to the streets largely on relationships in the family and the environment (Melson, 1991). In terms of this theory, the problems of the youths are located within the structures of the family and the environment (peer group, school, etc.), which may deny them meaningful roles and responsibilities as well as relationships and positive labels.

Brennan et al. (1978) integrated the social-psychological strain and control theories to explain the dynamics of the socio-psychological approach to the phenomenon of street children. The strain theory hypothesises that there is a strong possibility of youths running away from home if their personal needs in the family are not met. From this perspective, running away is a result of stress or strain that occurs within the home, especially in terms of parental relationships. The control theory postulates that runaways are the kinds of youths who did not make strong commitments to conventional norms during the socialization process and are therefore not controlled by social expectations.

The thrust of this study is informed by two interlocking frameworks, namely the sociological perspective and the socio-psychological perspective (Melson, 1991). Both these frameworks indicate that family disorganisation, as a result of adverse environmental conditions, is a major contributory factor to the street-child phenomenon and this therefore forms the focus of the researcher's examination of the "character" of these families. Family disorganisation in the context of this study was borne out of a multiplicity of factors, including issues relating to general family functioning, large female-headed households in the absence of father figures, and educational impoverishment exacerbated by general poverty.

\section{AIMS OF THE STUDY}

The overall aim of this study was to identify the general characteristics of families of street children. Specifically, the study aimed at determining the characteristics of families of street children in the rural areas of the Transkei. The researcher had a hunch that something was wrong 
with the home environments of these children. Traditionally, children were taken care of by their kith and kin and were the pride of the community. It is the strong family values and community bonds, maintained at all costs, that have kept the African families together against all odds, especially in the rural Transkei areas which were the hardest hit during the apartheid era (SiqwanaNdulo, 1993). Nowadays, street children in Umthatha, the capital of Transkei, are seen everywhere, for instance, at the doorsteps of the banks, in front of the city hall, at the supermarkets, cafes, hotels, garages, in the dump area, under the bridges, etc. The situation is becoming chaotic. The question as to what kind of families these children come from haunted the researcher. The main aim of the study can be summarized as follows: To determine the characteristics of families of street children.

\section{RESEARCH DESIGN AND METHODOLOGY}

\section{Research design}

As stated earlier, the aim of this study is to determine the characteristics of families of street children. To achieve the aims of the investigation, the researcher used an empirical study. This is an exploratory, quantitative study conducted in the rural Transkei from 1998 to 1999. An exploratory research design is appropriate when problems have been identified but our own understanding of the problems is quite limited. In an exploratory research design selection of participants is not a rigorous procedure. A few cases may be studied, or a large number may be selected in order to learn as much as possible about the problem (Yegidis \& Weinbach, 1996). Although the researcher would have liked to cover all the districts of the Transkei, this was not possible because the street children were "committed" to a shelter for street children in Umthatha and hence the specific districts visited by the researcher were determined by where the children's families of origin resided. Thus, the researcher could only interview thirty families for the study. The shelter has various programmes, namely a school programme, work therapy and employment programmes designed for the rehabilitation of the boys.

\section{Research sample}

De Vos (2002) states that a sample can be viewed as a sub-set of a population which we study in an effort to understand the entire population from which it was drawn. Thirty street boys between the ages ten and seventeen (10-17) years were randomly selected from a shelter for street children in Umthatha and, with the permission of the street shelter authorities, their families were traced and interviewed for the study. All thirty families resided in villages in various districts of the Transkei. All the families interviewed for the study had moved in the 1960s from where they were (but within the same locality) to make way for grazing fields. They lived within close proximity of members of their extended kin. The outstanding physical features of these families were a kraal indicating the existence of livestock, a small garden and fields for the subsistence of the family.

\section{Research tools}

A questionnaire, designed and administered by the researcher herself, was used to collect factual material that was needed for the study of the families of street children. In addition, an interview schedule, which contained questions that assisted the researcher to gain an insight into the "character" of these families, was designed and administered by the researcher to the respondents.

\section{Research methodology}

As indicated above, the research tools were administered by the researcher to the respondents. The main interviewee was the major care giver, usually a mother figure, but additional family members who were willing to participate in the study were not discouraged. Although the principle of 
confidentiality is not generally observed by disadvantaged African families, to safeguard any leakage of information, the main interviewee was asked whether she was agreeable to the idea that other family members could participate in the study. The interviewing sessions took approximately two hours and even longer, depending on the personality of the interviewee (extroverted or introverted) and the family tradition in terms of openness about family "secrets". All interviews were held at the home of the interviewees, usually twice or more, and were tape-recorded with the permission of the respondents. A maximum number of three families were interviewed per day in order to allow them enough time to respond to the researcher's questions. In some instances, only one family was interviewed because of the distance the researcher had to travel in order to reach the child's family home. A child-care worker from the street shelter which accommodated the children assisted the researcher in tracing and locating their families. This was necessitated by the close relationship she had with the children so that it was easier for them to open up to her than to the researcher about the exact location of the family home.

\section{RESULTS OF THE STUDY}

Of the thirty families interviewed for the study, 16 (53.3\%) were nuclear families and 14 (46.7\%), were extended families.

All these families were large, having between 2 and 12 family members. Of the thirty families interviewed, 3 (10\%) had one child, the street-child; $1(3.3 \%)$ family had two children, inclusive of the street-child, and another family (3.3\%) had three children; $6(20 \%)$ families had four children, $8(26.8 \%)$ had five and $7(23.4 \%)$, six children; 2 (6.6\%) families had seven children, $1(3.3 \%)$ eight, and another one $(3.3 \%)$, twelve children. This is a clear indication that these families are huge, with large numbers of children.

The majority of children of these families, $24(80 \%)$, had disturbed life experiences during their early childhood, for example death of a mother, parental abuse, family disorganisation leading to separation/divorce, and only $6(20 \%)$ had not experienced any disturbed early life. Of the thirty families interviewed for the study, 20 children (66.6\%), were raised by "foster families", 4 $(13.4 \%)$, by members of the extended kin, and the remaining $6(20 \%)$, were raised by their natural parents. This clearly indicates that these families were disorganised.

The majority of these families were female-headed. Of the thirty families interviewed for the study, $20(66.7 \%)$ were headed by females. The remaining $10(33.3 \%)$ were headed by both parents. The majority of the female-headed families were earning below the level of subsistence: 6 $(30 \%)$ were within the wage-range of $0-\mathrm{R} 200 ; 5(25 \%)$, within the wage-range of R400-599; and 5 (25\%) lived at the threshold of subsistence (R600-R799). Only 4 (20\%) families lived above the household subsistence level. This indicates the fact that the majority of these families were on the verge of being dysfunctional.

[The researcher was able to assess the level of poverty in each family by using a formula offered by the Institute for Planning Research at the University of Port Elizabeth (South African Institute of Race Relations, 1994/95) on the estimated household subsistence level (HSL) for Transkei rural and urban families (R759.06 for a family of six).]

Their earnings came from income-generating schemes, such as street vending, casual employment, social grants, hand-outs from neighbours, "Umgalelo" (stokvels), liquor sales as well as sales that were made from selling sheep, goats and pigs that belonged to the families.

Of the families interviewed, $25(83.4 \%)$ had church membership, even if they did not regularly attend church services. Only $5(16.6 \%)$ were not members of any church. This also points to some 
level of dysfunction, since religion has always been the pillar of African families. These families did not take kindly to their children being on the streets because living on the streets meant that children were not attending school. Of these families, 23 (76.6\%) were conscious of the significant role education could play in the lives of their children, and only $7(23.4 \%)$ were just not interested in getting their children educated. This implies that these families valued education and were conscious of the fact that their children would be educationally impoverished if they were not educated.

\section{DISCUSSION OF THE RESULTS}

A striking feature of families of street children is that they are often female-headed (Aptekar, 1996; Maphalala, 1996). The fathers are either absent or unavailable. In these families, since there are no father figures in the homes, boys are raised to be independent at a fairly early stage and forced to be able to fend for themselves. A few studies conducted in Africa have supported the viewpoint that most families of street children are female-headed. Two studies conducted ten years apart in Nairobi, Kenya, revealed that nearly 85 percent of heads of families of street children are women (Aptekar, 1996). Another study, also conducted in Nairobi, indicated that two thirds of families of street children are headed by women (Aptekar, 1996). Not only were these families headed by women, but by impoverished women (Aptekar, 1996). A study conducted in Kenya on these families reported that nine out of ten street children went to school without a meal; 85 percent ate only one meal a day (Aptekar, 1996). In another study of female-headed families of street children, also conducted in Kenya, three quarters of families lived in a single room (Aptekar, 1996). This underscores the plight of families of street children and implies a certain level of family disorganisation.

Researchers believe that many street children come from broken homes; as was reported earlier, the majority of these families are female-headed (Aptekar, 1996; Williams, 1996; Mncayi, 1996; Barrette, 1995; Pandey, 1991; Keen, 1990; Swart, 1988; Young et al., 1983; Brennan et al., 1978; Gullotta, 1979). Their homes are characterized by pain and suffering, which are a result of disturbed developmental life experiences, hunger, deprivation and step-parenting. Their parents are often abusive, neglectful, irresponsible and in many cases separated or divorced. Thus, the family becomes disorganised and eventually dysfunctional.

Generally, families of street children are characterised by poverty. This viewpoint has been endorsed by many researchers worldwide (Edigbo, 1996; Bourdillon, Dube \& Kamvura, 1996; Anyuru, 1996; Phiri, 1996; Maphalala, 1996; Swart-Kruger \& Donald, 1994 in Dawes \& Donald, 1994; Cockburn, 1991; Richter, 1989). They are poor both in terms of lack of resources and job opportunities, hence they resort to casual employment and other forms of income generation (Barrette, 1995).

Various studies have been conducted to endorse the conceptual frameworks that underpin this study. For instance, a Namibian study carried out in 1993 supports the sociological and the sociopsychological perspectives. In this study conducted in four Namibian cities, namely Windhoek, Rehoboth, Mariental and Otjuwarongo, the characteristics of families of street children were listed as follows: break-down of families, poverty at home, lack of financial support, large families, belonging to a single-parent family (usually a female-headed family) and having step-parents, refusal to attend school and poor educational facilities as well as peer group pressure (Rose-Julius, 1993). Another study conducted in 1996 on African children supported the sociological perspective of the phenomenon of street children. The study carried out in the two Swaziland towns of Mbabane and Manzini cited poverty (66.7\%) as the main characteristic of these families. Second was family disorganisation and physical abuse inflicted on children by parents and step- 
parents (17.9\%), and the last, cited by Maphalala (1996), was the existence of conflict within the families $(15.4 \%)$.

From the above characteristics of families of street children, the following assertions can be made:

- $\quad$ Families of street children are generally disorganised; and

- the significance of acknowledging this disorganisation is crucial for policy development and the provision of service delivery for them, and for the general functioning of families.

Within almost all societies six central principles can be identified which guide policy development and practice in relation to the desired functioning of families and the promotion of this functioning:

- Societal measures to enhance family functioning are an expression of the societal conviction regarding the worth and the value of family life to society as a whole;

- For the present and future well-being of society children require care, protection and security, and the family is the fundamental institution that can effectively execute this function. Children need to be nurtured within the social milieu of their own families;

- The strengthening and the preservation of family life is vital for societal programmes that are designed to promote the well-being of family members. To this end, it has been suggested that programmes should shift their focus from a curative / rehabilitative one to a developmental / preventive focus. This principle will be further discussed when the researcher presents Hoffmann's trilogy of continuums (Hoffmann, 1990:21-25) below;

- In a society where democratic ideals and values are cherished, parents have a right to raise their children according to their own values and norms without outside interference;

- One of the significant functions of the family is the protection of its members, especially the children. However, this function is enhanced by society through its legal and other systems;

- Social policy, as an expression of societal values, is significant for determining the fullest development of emotional, intellectual, physical and spiritual well-being of family members. Of further significance is the support that comes from other societal institutions that supplement the functions of the family, notably child-rearing, socialisation and protection of family members.

These principles highlight the family as fundamental in providing child-care and security. They also point to a societal responsibility for family enrichment through linking societal resources to families. Further, they underpin family functioning in terms of the fact that they are suggestive of the need to implement various programmes and projects for the enhancement of family functioning.

For families to function effectively, Hoffmann (1990) identifies 3 continuums along which societal efforts to promote family life should move. These are "...the institutional/residual continuum, the developmental/preventive/curative/rehabilitative continuum and the people-changing/ environment-changing continuum" (Hoffmann, 1990:21-25 in McKendrick, 1990). This trilogy of continuums will be used to explore the means to promote family functioning.

\section{The institutional/residual continuum}

At the residual end of the continuum, formal societal services for families come into play when the family can no longer render its caring and nurturing functions. Available state services would only 
be a reaction to a failed system of family support. Viewing this from an institutional perspective, there would be no room for developmental services. Services from an institutional point of view would be woven into the fabric of society and be available to all families and children, irrespective of whether they are in need or not (Hoffmann, 1990:210). The residual approach would be regarded as perpetuating a myth of an autonomous and self-sufficient family which is able to provide for its own needs with a minimum of outside resources. This is certainly not true in disadvantaged communities, where families experience problems like poverty and its related social ills that would lead to family disintegration unless the state intervenes appropriately.

\section{The developmental/preventive/curative/rehabilitative continuum}

Developmental and preventive services aim at enhancing the quality of family life, while at the opposite end of the continuum rehabilitative services are concerned with chronic needs and problems of families. A related objective of developmental and preventive services in promoting family welfare is to empower family members in order for them to grow and develop into responsible adults who will contribute meaningfully to society. Developmental intervention, as an ongoing process, focuses on the provision of community and societal resources in order to meet the basic needs of families. It implies moving from a curative/rehabilitative stance to a developmental and preventive focus. While deserving encouragement since prevention is preferred to cure, a preventive developmental approach may be difficult to apply in practice, especially among disadvantaged black families, since they have been riddled by years of colonialism, racism and apartheid.

In line with the new political dispensation, the developmental approach seeks to promote social welfare in South Africa (Gray \& Van Rooyen, 2002; Gray, 1997; Rankin, 1997). Both Gray and Rankin lament the fact that welfare policies of the past were a result of the policies of apartheid and also part of South Africa's colonial heritage.

They believe that a developmental approach is the best method of addressing the welfare problems of the disadvantaged in South Africa. They also believe that the South African welfare system should change its orientation from a treatment to a preventive perspective. They further believe that development means provision of resources, especially to the previously disadvantaged members of society, whilst at the same time empowering them for the enhancement of their functioning as members of families and of the larger society.

The thrust of the developmental approach is to promote the well-being of individuals and families so that they can experience change in their lives and become self-sufficient through empowerment and capacity building. This is significant for disadvantaged black families, whose problems have never been addressed from a developmental perspective. This approach will equip disadvantaged families with the necessary skills for growth, development and survival. It will also equip families of street children to deal with problems that need to be addressed through a developmental perspective.

\section{The people-changing/environment-changing continuum}

Societal intervention with families targets people-environmental changes that seek to strengthen the coping capacities of individual family members as well as influence the environment with which the family interacts (Hoffmann, 1990:24). Such a continuum is implicit in the ecological perspective, where intervention addresses the stresses arising from transactions between people and their environments, seeking a change either in the people or the environment or both (Germain \& Gitterman, 1979 in Turner, 1979). 
The ecological perspective asserts that there is a relationship between humans and their environment. The thrust of the approach is that people do not function in a vacuum, they are affected both positively and negatively by their environment. Since ecology seeks to maintain an adjustment between individuals and their environments, it would seem that individuals and families need environmental resources in order to function effectively in society. Similarly, the environment has to change in order to address family problems. This reciprocal relationship between humans and their environment has a significant impact on the functioning of families. Families will not be able to meet their needs if environmental resources are not available. Thus, the functioning of families depends to a great extent on the availability of resources.

\section{CONCLUSION}

Recognition of the family's centrality to human well being, and particularly the well-being of its members, has resulted in the family becoming a growing focus of interest for social scientists. However, often the thrust of this interest has not been towards trying to understand healthy family functioning, but trying to understand families in order to intervene within them to correct dysfunction in the family itself and/or in one or more of its members. The focus of social scientists should be on promoting healthy family functioning through programmes that are preventative, rather than on treatment, and be developmental in nature.

The majority of children continue to leave home and suffer on the streets mainly because of family disorganisation. More research needs to be conducted on the families of street children, in order to understand the challenges they face as well as the complexities of the street-child phenomenon. There is a great need to redefine the meaning of current family, and to design and implement the kind of policies that seek to empower the present families. We need to embrace the reality that both the child and the family are sub-systems of a larger system, the community. Programmes designed to address the challenges of families of street children should therefore be community based in order to enhance family functioning. Also, there is need to strengthen communities and to revisit those values that embrace uBuntu so that our communities are those that support family life and enhance family functioning for the benefit of those children who are in one way or the other disadvantaged.

\section{BIBLIOGRAPHY}

ANYURU, M. 1996. Uganda's street children. Africa Insight, 26(3):268-275.

APTEKAR, L. 1996. Street children in Nairobi. Africa Insight, 26(3):20-59.

BARRETTE, M. 1995. Street children need our care. Pretoria, Kagiso Publishers.

BLACK, M. 1993. Report on street and working children. Florence, Italy, UNICEF, International Child Development Centre, February, 15-25.

BOURDILLON, M.F.C., DUBE, L. \& KAMVURA, L. 1996. Working with street boys in Harari. Africa Insight, 26(3):260-267.

BRENNAN, T., HUIZINGA, D. \& ELLIOT, D. 1978. The social psychology of runaways. Lexington, M.A.: D.C. Heath \& Co.

COCKBURN, A. 1991. Street children: Characteristics and dynamics of the problem. Child Welfare, 17(1):6.

DAWES, A. \& DONALD, D. 1994. Childhood and adversity: Psychological perspectives from South African research. Cape Town: Philip. 
DE VOS, A.S. 2002. Research at grass roots: for the social science professions ( $2^{\text {nd }}$ ed). Pretoria: J.L. Van Schaik Publishers.

EDIGBO, P. 1996. Street children: the core of child abuse and neglect in Nigeria. Africa Insight, 26(3):244-249.

GRAY, M. \& COLLETT VAN ROOYEN, C.A.J. 2002. The strengths perspectives in social work: Lessons from practice. Social Work/Maatskaplike Werk, 38(3):193-200.

GRAY, M. 1997. A pragmatic approach to social development. Social Work/Maatskaplike Werk, 33(3):210-233.

GULlOTTA, T. 1979. Family relationships of the runaway child. Social Casework: The Journal of Contemporary Social Work, (February):111-114.

HOFFMANN, W. 1990. Social work practice in family and children's services. In: McKENDRICK, B. (ed.) Social work in action. Pretoria: Haum Tertiary: 21-25.

KEEN, J. 1990. A window on the inner world of street children. The Child Care Worker, 8(5):2.

KUSE, T. 2001. Family functioning and street children in the Transkei. Johannesburg: University of the Witwatersrand. (PhD thesis)

MAPHALALA, T. 1996. Street children in Swaziland. Africa Insight, 26(3):282-288.

McKENDRICK, B. (ed) 1990. Social work in action. Cape Town: Haum Tertiary.

McWHIRTER, J.J., McWHIRTER, B.T., McWHIRTER, A.M. \& McWHIRTER, E.H. 1998. At risk youth: a comprehensive response. USA: Brooks/Cole.

MELSON, B.K.H. 1991. Runaway adolescence: a family systems perspective. USA. St Louis University. (Ph D thesis)

MNCAYI, P. 1996. Street children now. Child and Youth Care, 14(3):4-5.

PANDEY, R. 1991. Street children of India: A situational analysis. Allahabad, India: Chugh Publications.

PHIRI, J. 1996. The plight of street children in Zambia. Africa Insight, 26(3):276-281.

RANKIN, P. 1997. Developmental social welfare: challenges facing South Africa. Social Work/Maatskaplike Werk, 33(3):184-192.

RICHTER, L. \& SWART-KRUGER, J. 1996. Society makes survival a crime. Child Youth Care, 14(6):17-19.

RICHTER, L. \& VAN DER WALT, M. 1996. The psychological assessment of South African street children. Africa Insight, 26(3):211-220.

RICHTER, L. 1989. South African street children: comparisons with Anglo-American runaways. Paper presented at a regional conference of the International Association for Crosscultural Psychology, Amsterdam, June 27-July 1.

ROSE-JULIUS, S.M.H. 1993. A study of four urban centres in Namigia to determine the cyclic nature of streetism among children and suggestions for prevention, policy-making and programme planning. Pretoria: University of South Africa. (PhD thesis) 
SIQWANA-NDULO, N.W. 1993. Rural African family structure in the Transkei. USA: University of California. (PhD thesis)

SOUTH AFRICAN INSTITUTE OF RACE RELATIONS, 1994/95.

SWART, J. 1988. Street-wise: opening the way to self-actualization for the street child. Africa Insight, 18(1):32-41.

SWART-KRUGER, J. \& DONALD, D. 1994. Children of the South African streets. In: DAWES, A. \& DONALD, D. Childhood and adversity: psychological perspectives from South African research, Cape Town: Phillip D.

SWART-KRUGER, J. 1996. An imperfect fit: Street children and state intervention - the South African case. Africa Insight, 26(3):231-236.

TURNER, F. 1979. Social work treatment $\left(2^{\text {nd }}\right.$ ed). New York: Free Press.

WILLIAMS, C.G. 1996. Street children and abuse of power. Africa Insight, 26(3):221-230.

YEGIDIS, B.L. \& WEINBACH, R.W. 1996. Research methods for social workers. London: Allan Bacon.

YOUNG, R., GODFREY, W., MATTHEWS, B. \& ADAMS, G. 1983. Runaways: A review of negative consequences. Family Relations, 32:275-281.

Prof Thobeka Mashologu-Kuse, Department of Social Work, Nelson Mandela Metropolitan University, Port Elizabeth, South Africa. 